\title{
Evaluation of Positive Inotropic Activity Induced bya Danazol Derivative in Isolated Rat Heart Model
}

\author{
L. Figueroa-Valverde ${ }^{1 *}$, F. Díaz-Cedillo ${ }^{2}$, E. García-Cervera ${ }^{1}$, E. Pool Gómez ${ }^{1}$, M. López-Ramos ${ }^{1}$, \\ M. Rosas-Nexticapa ${ }^{3}$, R. Mendoza-López ${ }^{3}$, I. May-Gil ${ }^{1}$, A. Sarao ${ }^{1}$
}

${ }^{1}$ Laboratory of Pharmaco-Chemistry, Faculty of Chemical Biological Sciences, The University Autonomous of Campeche, Campeche, Mexico; ${ }^{2}$ Escuela Nacional de Ciencias Biológicasdel Instituto Politécnico Nacional, Prol. Carpio y Plan de Ayala s/n Col, Santo Tomas, Mexico City, Mexico; ${ }^{3}$ Facultad de Nutrición, Campus Xalapa, Universidad Veracruzana, Veracruz, Mexico.

Email: *lauro_1999@yahoo.com

Received April 21 $1^{\text {st }}, 2013$; revised June $3^{\text {rd }}, 2013$; accepted June $15^{\text {th }}, 2013$

Copyright (C) 2013 L. Figueroa-Valverde et al. This is an open access article distributed under the Creative Commons Attribution License, which permits unrestricted use, distribution, and reproduction in any medium, provided the original work is properly cited.

\begin{abstract}
There is scarce information about the effects of danazol and its derivatives at cardiovascular level. In addition, to date the cellular site and mechanism of action of danazol at the cardiovascular level is very confusing. In order to clarify those phenomena in this study, a danazol derivative was synthesized with the objective of evaluating its activity on perfusion pressure and coronary resistance and comparing this phenomenon with the effect exerted by danazol. The Langendorff technique was used to measure changes on perfusion pressure and coronary resistance in an isolated rat heart model in the absence or presence of danazol and its derivative. Additionally, to characterize the molecular mechanism involved in the inotropic activity induced by danazol derivative was evaluated by measuring left ventricular pressure in the absence or presence of following compounds; flutamide, prazosin, metoprolol, indomethacin and nifedipine. The results showed that danazol derivative significantly increased the perfusion pressure and coronary resistance in comparison with the control conditions and danazol. Additionally, other data indicate that the danazol derivative increases left ventricular pressure in a dose-dependent manner; nevertheless, this phenomenon was significantly inhibited by flutamide. These data suggest that danazol derivative induces positive inotropic activity through of the activation androgen receptor.
\end{abstract}

Keywords: Danazol Derivative; Langendorff; Inotropic Activity

\section{Introduction}

Several reports which indicate that congestive heart failure (CHF) is a main cause of death in patients with heart disease [1,2]. For the treatment of CHF has been several drugs such as the digitalis glycosides, unfortunately the use of these agents is limited by their narrow therapeutic window and their propensity to cause life-threatening arrhythmias $[3,4]$. Therefore, there has been a resurgence of interest in cardiotonic steroid derivatives, it is important to mention that these molecules exert a large number of effects in cardiac tissue [5]. For example, the strophanthidin (steroid derivative) increases the force of contraction by changes in the calcium levels [6]. In addition, there are studies that show the synthesis of a steroid derivative (F90927) which exerts a positive inotropic activity in cardiac muscle via activation of the L-type $\mathrm{Ca}^{2+}$

\footnotetext{
"Corresponding author.
}

channel [7]. Additionally, recently other type of steroid derivative (Furosemide-Pregnenolone) was synthesized which showed apositive inotropic activity on cardiac muscle via activation of the L-type $\mathrm{Ca}^{2+}$ channel [8].

On the other hand, a series of steroid derivatives $[9,10]$ were synthesized which showed a positive inotropic effect, mainly by inhibition of $\mathrm{Na}^{+}, \mathrm{K}^{+}$-ATPase. Nevertheless, other reports indicate that $14 \beta$-hydroxyprogesterone [11] increases the contractility of isolated cardiac tissue via glycoside receptor. Other studies showed that $20 \mathrm{R}$ $14 \beta$ amino-3 $\beta$-rhamnosyl-5 $\beta$-pregnan-20 $\beta$-ol can also induce a positive inotropic action in a dog model of induced heart failure and this effect could be through its high affinity to $\mathrm{Na}^{+}, \mathrm{K}(+)$-ATPase receptor [12]. All these data show that several steroid derivatives exert inotropic effects on the cardiovascular system; nevertheless, there is scarce information about the effects of danazol and its derivatives at cardiovascular level. In addition, it 
is important to mention that also the cellular site and molecular mechanism involved at cardiovascular level are very confusing. In order to clarify those phenomena in this study, a danazol derivative was synthesized with the objective of to evaluate its activity on perfusion pressure and coronary resistance in a model of isolated rat hearts, using the Langendorff technique and compare this phenomenon with the effect exerted by danazol. Additionally, to evaluate the molecular mechanism involved in the inotropic activity induced by the danazol derivative on left ventricular pressure, the following compounds were used as pharmacological tools; flutamide (antagonist of androgen receptor) [13], (prazosin [ $\alpha_{1}$ adrenoreceptor antagonist) [14], metroprolol (selective $\beta_{1}$ receptor blocker) [15], nifedipin (antagonist of calcium-channell) [16] and indomethacin (inhibitor of prostaglandin synthesis) [17].

\section{Materials and Method}

\subsection{Chemical Synthesis}

4-allylphenyl 4-[(2-aminoethyl)amino]-4-oxobutanoate (Compound 1; Figure 1) was prepared according to a previously reported method [18]. The other compounds evaluated in this study were purchased from Sigma-Aldrich Co., Ltd. The melting point for the danazol deriva- tive was determined on an Electrothermal (900 model). Infrared spectra (IR) were recorded using $\mathrm{KBr}$ pellets on a Perkin Elmer Lambda 40 spectrometer. ${ }^{1} \mathrm{H}$ and ${ }^{13} \mathrm{C}$ NMR spectra were recorded on a Varian VXR-300/5 FT NMR spectrometer at 300 and $75.4 \mathrm{MHz}$ in $\mathrm{CDCl}_{3}$ using TMS as internal standard. EIMS spectra were obtained with a Finnigan Trace GCP olaris Q Spectrometer. Elementary analysis data were acquired from a Perkin Elmer Ser. II CHNS/0 2400 elemental analyzer.

2.2. N-[3-(1-Hydroxy-10a,12a-dimethyl-2,2,3a,3b, $4,5,10,10 \mathrm{a}, 10 \mathrm{~b}, 11,12,12 \mathrm{a}-d o d e c a h y d r o-1 H$ 7-oxa-8-aza-dicyclopenta[a,h]phenan-thren1-ylethynylamino)-3-(3-hydroxy-naphtalen-2 -yl)-propyl]-succinamic acid 3-allyl-5-methoxy-phenyl ester

A solution of danazol (100 mg, $0.29 \mathrm{mmol})$, 2-hydroxy1-naphthaldehyde (50 mg, $0.29 \mathrm{mmol})$, 4-allylphenyl 4-[(2-aminoethyl)amino]-4-oxobutanoate $\quad(80 \mu \mathrm{l}, \quad 0.29$ $\mathrm{mmol})$ and cupric chloride dehydrate $(0.35 \mathrm{mmol})$ in 10 $\mathrm{mL}$ of methanol was stirred for $24 \mathrm{~h}$ at room temperature. The reaction mixture was evaporated to dryness under reduced pressure, the residue washed 3 times with water. Then the precipitate was separated and dried at room temperature.<smiles>C#CC1(O)CCC2C3CCC4=Cc5oncc5CC4(C)C3CC[C@]21C</smiles>

1<smiles>O=Cc1c(O)ccc2ccccc12</smiles>

2

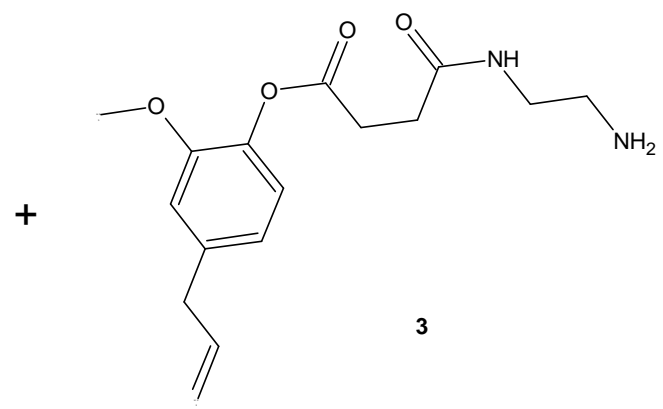<smiles>C=CCc1ccc(OC(=O)CCC(=O)NCCN(C#CC2(O)CCC3C4CCC5=Cc6oncc6CC5(C)C4CCC32C)c2c(O)ccc3ccccc23)c(OC)c1</smiles>

Figure 1. Synthesis of the danazol derivative (4). Reaction between danazol (1), 2-hydroxy-1-naphthaldehyde (2) and 4-allylphenyl 4-[(2-aminoethyl)amino]-4-oxobuta-noate (3) to form $4 . \mathrm{i}=$ ethanol/rt. 


\subsection{Biological Method}

All experimental procedures and protocols used in this investigation were reviewed and approved by the animal care and use Committee of University Autonomous of Campeche (UAC) and were in accordance with the Guide for the Care and Use of Laboratory Animals [19]. Male rats Wistar; weighing $200-250 \mathrm{~g}$ were obtained from UAC.

\subsubsection{Reagents}

All drugs were dissolved in methanol and different dilutions were obtained using Krebs-Henseleit solution ( $\leq$ $0.01 \%, \mathrm{v} / \mathrm{v})$.

\subsubsection{Langendorff Technique}

Briefly, the male rat $(200-250 \mathrm{~g})$ was anesthetized by injecting them with pentobarbital at a dose rate of 50 $\mathrm{mg} / \mathrm{Kg}$ body weight. Then the chest was opened, and a loose ligature passed through the ascending aorta. The heart was then rapidly removed and immersed in ice cold physiologic saline solution. The heart was trimmed of non-cardiac tissue and retrograde perfused via a noncirculating perfusion system at a constant flow rate. It is important to mention that perfusion medium was the Krebs-Henseleit solution $\left(\mathrm{pH} 7.4,37^{\circ} \mathrm{C}\right)$ composed of (mmol); $117.8 \mathrm{NaCl} ; 6 \mathrm{KCl} ; 1.75 \mathrm{CaCl}_{2} ; 1.2 \mathrm{NaH}_{2} \mathrm{PO}_{4}$; $1.2 \mathrm{MgSO}_{4} ; 24.2 \mathrm{NaHCO}_{3} ; 5$ glucose and 5 sodiumpyruvate. The solution was actively bubbled with a mixture of $\mathrm{O}_{2} / \mathrm{CO}_{2}$ (95:5). The coronary flow was adjusted with a variable speed peristaltic pump. An initial perfusion rate of $15 \mathrm{ml} / \mathrm{min}$ for $5 \mathrm{~min}$ was followed by a 25 min equilibration period at a perfusion rate of $10 \mathrm{ml} /$ min. All experimental measurements were done after this equilibration period. It is important to mention that number of animals used in each experiment was equal to 8 .

\subsubsection{Induction of Congestive Heart Failure (CHF)}

CHF was development mainly of a method previously reported [20], in this process the pentobarbital (100 $/ \mathrm{Kg} \cdot \mathrm{mg}$ ) was administered through of cannula inserted in the aorta to induce CHF.

\subsubsection{Perfusion Pressure}

Evaluation of perfusion pressure changes induced by drugs administration was assessed using a pressure transducer connected to the chamber, where the hearts were mounted. The pressure transducer also was connected with to an MP100 data acquisition system.

\subsubsection{Inotropic Activity}

Contractile function was assessed by measuring left ventricular developed pressure (LVdP), using a saline-filled latex balloon $(0.01 \mathrm{~mm}$, diameter) inserted into the left ventricle via the left atrium. It is important to mention that latex balloon was bound to cannula which was linked to pressure transducer that was connected with the MP100 data acquisition system.

\subsection{Biological Evaluation}

\subsubsection{First Stage}

Effect induced by danazol and its derivative on perfusion pressure: Changes in perfusion pressure as a consequence of increases in time (3-18 min) in the absence (control) or presence of danazol and its derivative at a concentration of $1 \times 10^{-9} \mathrm{mmol}$ were determined. The effects were obtained in isolated hearts perfused at a constant-flow rate of $10 \mathrm{ml} / \mathrm{min}$.

Evaluation of effects exerted by danazol and its derivative on coronary resistance: The coronary resistance in the absence (control) or presence of the danazol and its derivative at a concentration of $1 \times 10^{-9} \mathrm{mmol}$ was evaluated. The effects were obtained in isolated hearts perfused at a constant flow rate of $10 \mathrm{ml} / \mathrm{min}$. Since a constant flow was used changes in coronary pressure reflects the changes in coronary resistance.

\subsubsection{Second Stage}

Effects induced by the danazol derivative on left ventricular pressure through both $\alpha_{1}$ and $\beta_{1}$ adrenergic blockers: The boluses $(50 \mu \mathrm{l})$ of the danazol derivative $\left[1 \times 10^{-9}\right.$ to $\left.1 \times 10^{-4} \mathrm{mmol}\right]$ were administered and the corresponding effect on the left ventricular pressure was evaluated. It is important to mention that the bolus injection administered was done at the point of cannulation. The dose-response curve (control) was repeated in the presence of prazosin or metoprolol at a concentration of $1 \times 10^{-6} \mathrm{mmol}$ (duration of the pre-incubation with prazosin or metoprolol was for a period of $10 \mathrm{~min}$ ).

Effects of the danazol derivative on left ventricular pressure through the calcium channel: Intracoronary boluses $(50 \mu \mathrm{l})$ of the danazol derivative $\left[1 \times 10^{-9}\right.$ to $\left.1 \times 10^{-4} \mathrm{mmol}\right]$ were administered and the corresponding effect on the left ventricular pressure was evaluated. The dose-response curve (control) was repeated in the presence of nifedipine at a concentration of $1 \times 10^{-6} \mathrm{mmol}$ (duration of the pre-incubation with nifedipine was for a period of $10 \mathrm{~min}$ ).

Effect exerted by the danazol derivative on left ventricular pressure in the presence of indomethacin. The boluses $(50 \mu \mathrm{l})$ of the danazol derivative $\left[1 \times 10^{-9}\right.$ to $\left.1 \times 10^{-4} \mathrm{mmol}\right]$ were administered and the corresponding effect on the left ventricular pressure was evaluated. It is important to mention that the bolus injection administered was done in the point of cannulation. The doseresponse curve (control) was repeated in the presence of indomethacin at a concentration of $1 \times 10^{-6} \mathrm{mmol}(\mathrm{du}-$ 
ration of the pre-incubation with indomethacin was for a period of $10 \mathrm{~min}$ ).

Effects induced by the danazol derivative on left ventricular pressure through androgen receptor: Intracoronary boluses $(50 \mu \mathrm{l})$ of the danazol derivative $[1 \times$ $10^{-9}$ to $\left.1 \times 10^{-4} \mathrm{mmol}\right]$ were administered and the corresponding effect on the left ventricular pressure was determined. The dose-response curve (control) was repeated in the presence of flutamide at a concentration of $1 \times$ $10^{-6} \mathrm{mmol}$ (duration of the pre-incubation with flutamide was for a period of $10 \mathrm{~min}$ ).

It is important to mention that dose of antagonist drugs used in this study have been reported previously [20-25].

\subsection{Statistical Analysis}

The obtained values are expressed as average \pm SE, using each heart as its own control. The data obtained were put under an analysis of variance (ANOVA) using the Bonferroni correction factor [26]. The differences were considered significant when $p$ was equal or smaller than 0.05 .

\section{Results}

\subsection{Chemical Synthesis}

The yield of the reaction product (see Figure 1) was $42 \%$ with melting point of $159^{\circ} \mathrm{C}$. In addition, the spectroscopic analyses show signals for IR $\left(\mathrm{V}_{\max }, \mathrm{cm}^{-1}\right)$ at 3300 , 1720, 1680, 1620 and 1162; In addition, the chemical shifts of the spectroscopic analyses of ${ }^{1} \mathrm{H}$ NMR and ${ }^{13} \mathrm{C}$ NMR for the dehydroepiandrosterone derivative are showed in the Tables 1 and 2. Finally, the results of mass spectroscopy (MS) (70 ev) shown; m/z $753.54[\mathrm{M}+, 12]$ $521.67,273.43,471.72$. Additionally, the elementary analysis data for the danazol derivative $\left(\mathrm{C}_{47} \mathrm{H}_{51} \mathrm{~N}_{3} \mathrm{O}_{6}\right)$ were calculated $(\mathrm{C}, 74.88 ; \mathrm{H}, 6.82 ; \mathrm{N}, 5.57 ; \mathrm{O}, 12.73)$ and found $(\mathrm{C}, 74.76 ; \mathrm{H}, 6.80)$.

\subsection{Biological Evaluation}

\subsubsection{First Stage}

In this study, the activity induced by the danazol and its

Table 1. ${ }^{1} \mathrm{H}$ NMR (300 $\left.\mathrm{MHz}, \mathrm{CDCl}_{3}\right)$ data for the danazol derivative.

\begin{tabular}{l}
\hline $\boldsymbol{\delta}_{\boldsymbol{H}} \boldsymbol{\text { ppm }}$ \\
\hline $1 \mathrm{H}$ NMR $(300 \mathrm{MHz}, \mathrm{CDCl} 3) 0.95(\mathrm{~s}, 1 \mathrm{H}), 1.00(\mathrm{~s}, 3 \mathrm{H}), 1.02(\mathrm{~m}$, \\
$1 \mathrm{H}), 1.03(\mathrm{~s}, 3 \mathrm{H}), 1.06(\mathrm{~s}, 3 \mathrm{H}), 1.18-1.40(\mathrm{~m}, 4 \mathrm{H}), 1.50-1.91(\mathrm{~m}$, \\
$9 \mathrm{H}), 2.20-2.40(\mathrm{~m}, 2 \mathrm{H}), 2.49(\mathrm{t}, J=6.8 \mathrm{~Hz}, 2 \mathrm{H}), 2.74(\mathrm{t}, J=6.8$ \\
$\mathrm{Hz}, 2 \mathrm{H}), 3.24(\mathrm{t}, J=6.03,2 \mathrm{H}), 3.36(\mathrm{~m}, 1 \mathrm{H}), 3.44(\mathrm{t}, J=6.03,2 \mathrm{H})$, \\
$3.80(\mathrm{~s}, 3 \mathrm{H}), 5.04(\mathrm{~d}, \mathrm{~d}, J=2.3 \mathrm{~Hz}, J=11.0 \mathrm{~Hz}, 1 \mathrm{H}), 5.07(\mathrm{~d}, \mathrm{~d}, J=$ \\
$2.3 \mathrm{~Hz}, J=16.0 \mathrm{~Hz}, 1 \mathrm{H}), 5.95(\mathrm{~m}, 1 \mathrm{H}), 6.62(\mathrm{~s}, 1 \mathrm{H}), 6.72(\mathrm{~d}, J=$ \\
$8.0 \mathrm{~Hz}, 2 \mathrm{H}), 7.08(\mathrm{~d}, J=9.0 \mathrm{~Hz}, 1 \mathrm{H}), 7.10(\mathrm{~d}, J=9.0 \mathrm{~Hz}, 1 \mathrm{H})$, \\
$7.25(\mathrm{~m}, 2 \mathrm{H}), 7.32-739(\mathrm{~m}, 3 \mathrm{H}), 7.59(\mathrm{~d}, J=8.0 \mathrm{~Hz}, 1 \mathrm{H}), 7.98(\mathrm{~s}$, \\
$1 \mathrm{H}), 8.11(\mathrm{broad}, 3 \mathrm{H}) \mathrm{ppm}$.
\end{tabular}

Table 2. ${ }^{13} \mathrm{C}$ NMR (300 $\left.\mathrm{MHz}, \mathrm{CDCl}_{3}\right)$ data for the danazol derivative.

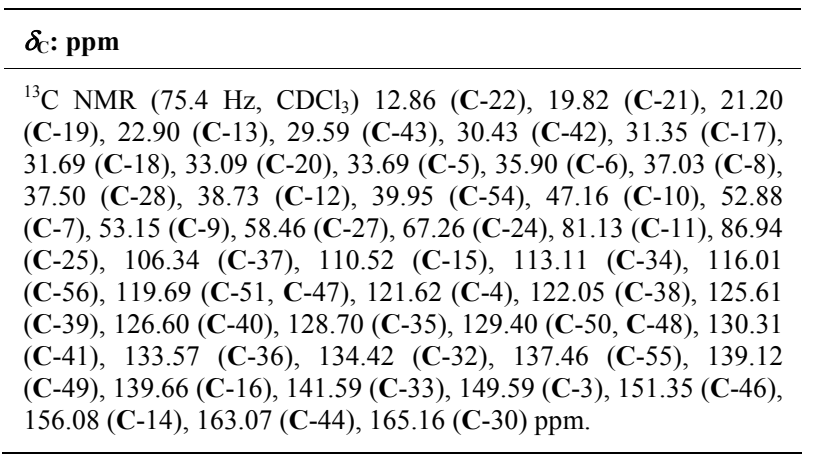

derivative on perfusion pressure and coronary resistance in the isolated rat heart was evaluated. The results obtained from changes in perfusion pressure as a consequence of increases in the time (3 to $18 \mathrm{~min}$ ) in the absence (control) or in the presence of danazol and its derivative (see Figure 2), showed that steroid derivative [1 $\left.\times 10^{-9} \mathrm{mmol}\right]$ significantly increase the perfusion pressure $(p=0.05)$ in comparison with the control conditions and danazol (see Figure 3) at a concentration of $1 \times 10^{-9}$ mmol. Additionally, another result (see Figure 4) showed that coronary resistance, calculated as the ratio of perfusion pressure at coronary flow assayed $(10 \mathrm{ml} / \mathrm{min})$ was significantly higher $(p=0.06)$ in the presence of steroid derivative $\left[1 \times 10^{-9} \mathrm{mmol}\right]$ than in control conditions and danazol $\left[1 \times 10^{-9} \mathrm{mmol}\right]$.

\subsubsection{Second Stage}

Figure 5 showed that the danazol derivative induces an increase on LVP in a dose dependent manner [ $1 \times$ $10^{-9}$ to $\left.1 \times 10^{-4} \mathrm{mmol}\right]$ and that this effect was not inhibited by prazosin, metoprolol, indomethacin or nifedipine at a concentration of $1 \times 10^{-6} \mathrm{mmol}$. Other data showed that effect induced by the danazol derivative on LVP (Figure 6) in the presence of flutamide at a concentration of $1 \times 10^{-6} \mathrm{mmol}$ was significantly blocked $(p=0.05)$.

On the other hand, other results showed that that flutamide induces decrease of LVP through of time (Figure 7) compared with the control conditions. However, DEEBNA significantly increased LVP and this effect was inhibited by significantly flutamide $(p=$ 0.05). Finally, Figure 8 shows that flutamide low the resistance coronary in comparison with the control. In addition, the effect exerted by DEEBNA on coronary resistance was significantly blocked $(p=0.05)$ by flutamide.

\section{Discussion}

\subsection{Synthesis Chemical}

In this study a danazol derivative was synthesized using 


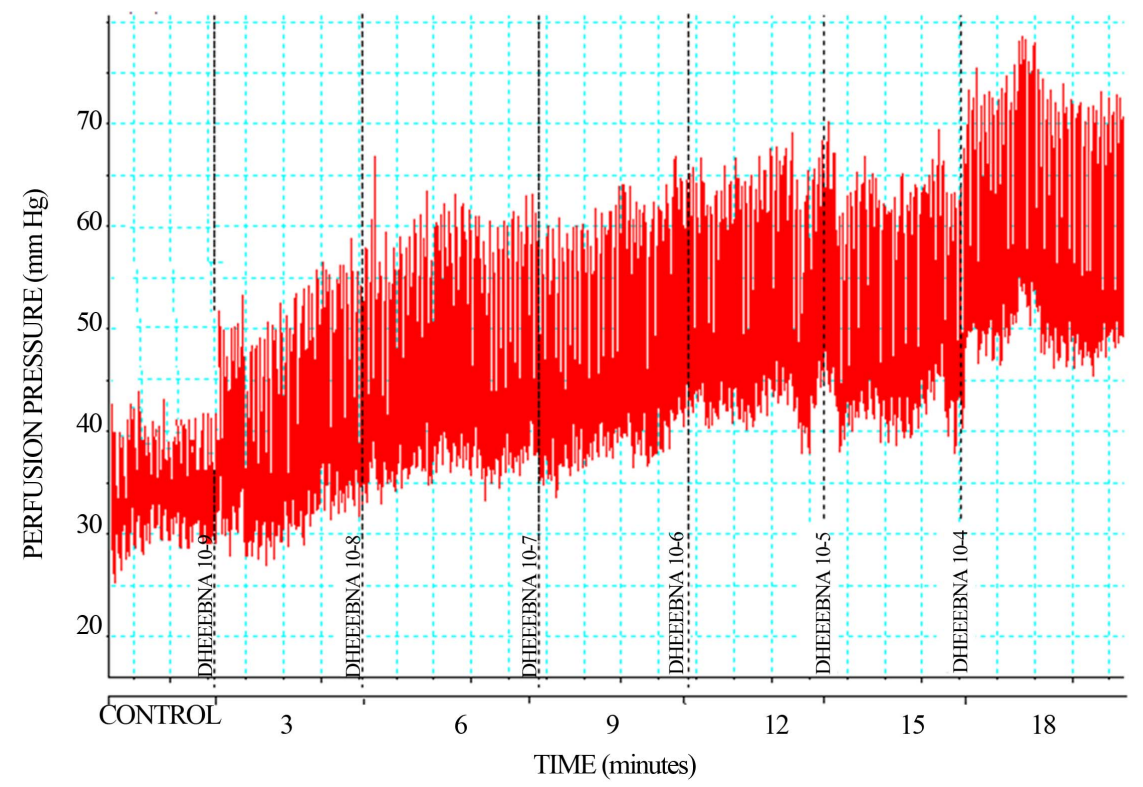

Figure 2. Effect exerted by the danazol derivative (DEEBNA) through of time (3 - 18 minutes). Each bar represents the mean \pm S.E. of 8 experiments.

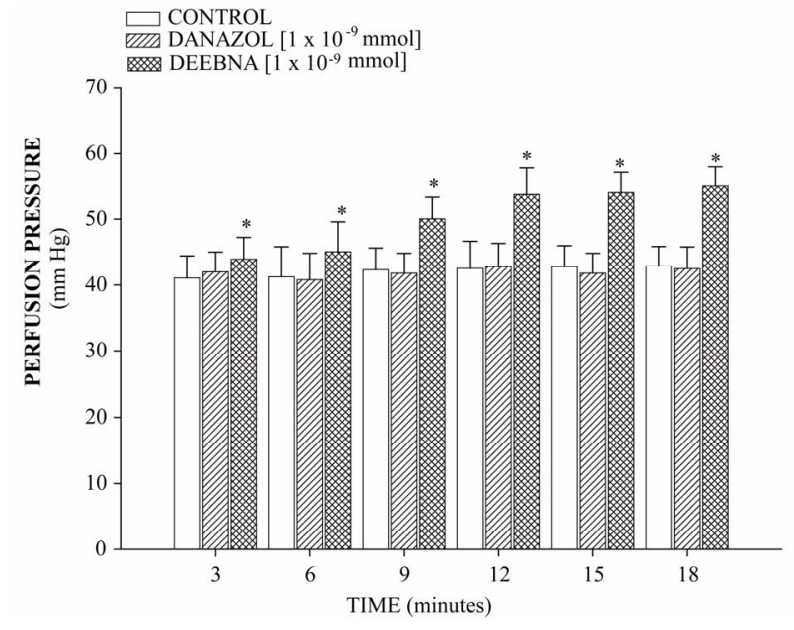

Figure 3. Effect induced by danazol and its derivative (DEEBNA) on perfusion pressure. The results show that DEEBNA significantly increase perfusion pressure $(p=$ 0.05) through time in comparison with the control conditions and danazol. Each bar represents the mean \pm S.E. of 8 experiments.

the three component system (see Figure 1). It is important to mention that many procedures are used in the three component system for the formation of several compounds. The most widely practiced method employs boric acid [27], silica sulfuric acid [28], poly (4-vinylpyridine codivynylbenzene)-Cu(II) complex [29], silica triflate [30] and phosphorus [31] Nevertheless, despite its wide scope, the former protocols suffer from several drawbacks; some reagents have a limited stability and its preparation can be dangerous. Therefore, in this study the danazol (1) was made reacting with 2-hydroxy-

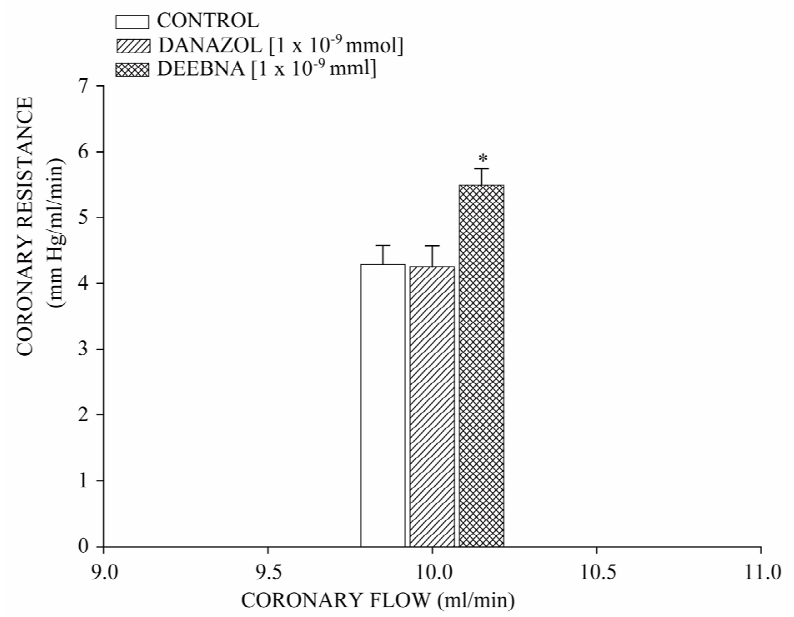

Figure 4. Activity exerted by danazol and its derivative (DEEBNA) on coronary resistance. The results show that coronary resistance was higher $(p=0.06)$ in the presence of DEEBNA in comparison with the control conditions and danazol. Each bar represents the mean \pm S.E. of 8 experiments.

1-naphthaldehyde (2) and 4-allylphenyl 4-[(2-aminoethyl) amino]-4-oxobutanoate (3) in ethanol to form the compound danazol derivative (4).

On the other hand, the structure of danazol derivative was confirmed using IR and NMR spectroscopy data. The IR spectra contained characteristic vibrations $\left(\mathrm{V}_{\max }\right.$, $\mathrm{cm}^{-1}$ ) at 3300 for hydroxyl group; at 1720 for ester group; at 1680 for amide group; 1620 for alkenyl group and at 1162 for the tertiary amino group. The ${ }^{1} \mathrm{H}$ NMR spectrum of the danazol derivative shows signals at 0.95 and 1.00 ppm for methyl groups of steroid nucleus; at $1.02-2.40$ 


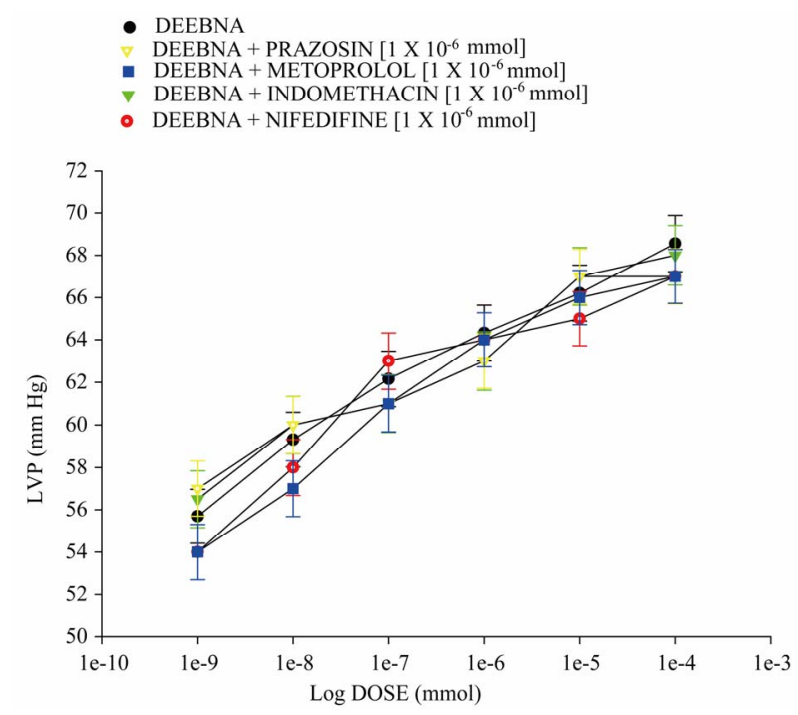

Figure 5. Effect exerted by the danazol derivative (DEEBNA) on left ventricular pressure (LVP) through of both $\alpha_{1}$ and $\beta_{1}$ adrenergic receptors, synthesis of pros-taglandins or calcium channel activation. DEEBNA $\left[1 \times 10^{-9}\right.$ to $1 \times 10^{-4}$ mmol] was administered (intracoronary boluses, $50 \mu \mathrm{l}$ ) and the corresponding effect on the LVP was evaluated in the absence and presence of prazosin, metoprolol, indomethacin or nifedipine. The results showed that activity induced by DEEBNA on LVP was not inhibited in the presence of these compounds $\left[1 \times 10^{-6}\right]$. Each bar represents the mean \pm S.E. of 8 experiments.

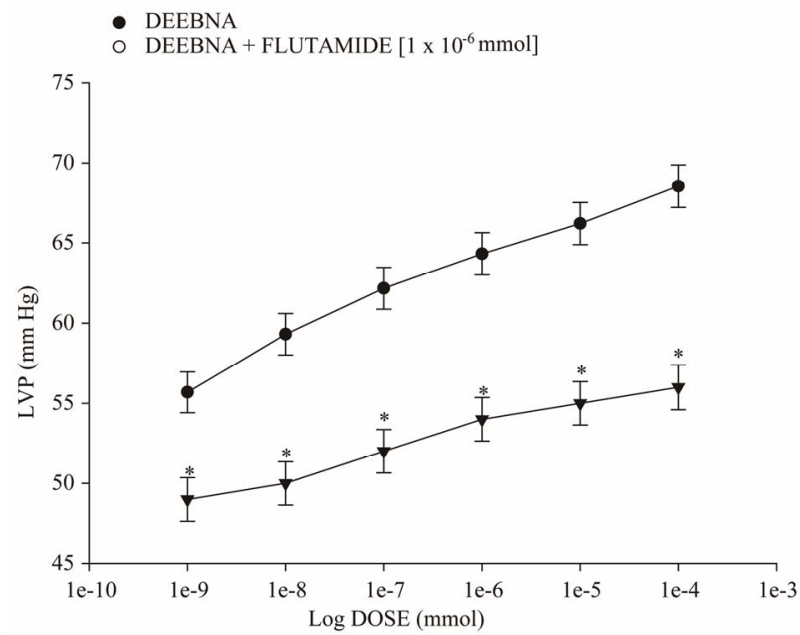

Figure 6. Effects induced by the danazol derivative (DEEBNA) on left ventricular pressure (LVP) through androgen receptors. Intracoronary boluses $(50 \mu \mathrm{l})$ of DEEBNA $\left[1 \times 10^{-9}\right.$ to $1 \times 10^{-4} \mathrm{mmol}$ ] were administered and the corresponding effect on the LVP was determined. The results showed that DEEBNA increase the LVP in a dependent dose manner and this effect was significantly inhibited $(p=0.05)$ in the presence of flutamide $\left[1 \times 10^{-6}\right]$. Each bar represents the mean \pm S.E. of 8 experiments.

and $6.62 \mathrm{ppm}$ for protons involved in the steroid nucleus. In addition, other signals at $2.49-2.74$ ppm for methyl-

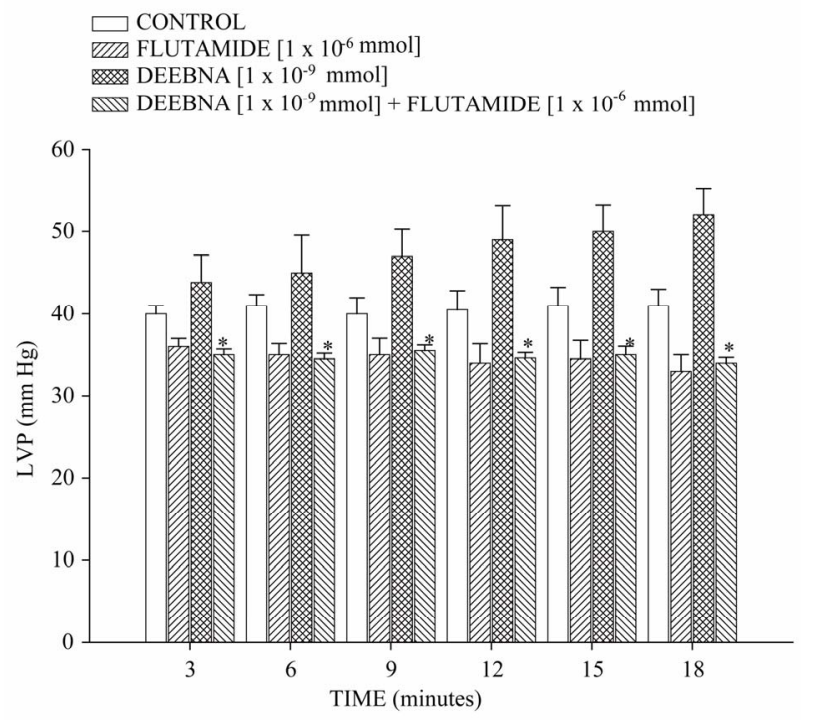

Figure 7. Activity induced by flutamide in the absence or presence of danazol derivative (DEEBNA) on left ventricular pressure (LVP). The results indicate that the flutamideinduces decrease on LVP compared with the control conditions. Other data indicate that DEEBNA increase LVP and this effect was inhibited significantly by flutamide $(p=$ 0.05). Each bar represents the mean \pm S.E. of 8 experiments.

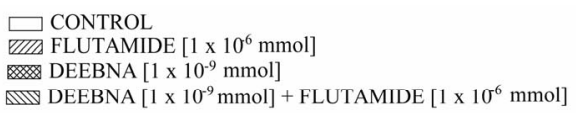

$\square$ CONTROL

UII FLUTAMIDE $\left[1 \times 10^{6} \mathrm{mmol}\right]$ DEEBNA [1 x 10-9 $\mathrm{mmol}]$

DEEBNA [1 $\left.110^{-9} \mathrm{mmol}\right]+$ FLUTAMIDE $\left[1 \times 10^{6} \mathrm{mmol}\right]$

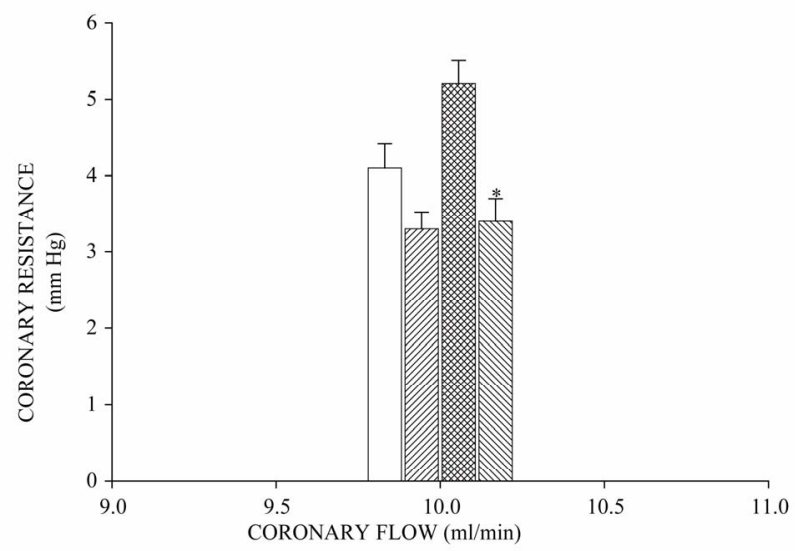

Figure 8. Activity exerted by flutamide in the absence or presence of danazol derivative (DEEBNA) on coronary resistance. The results show that flutamide decreases the coronary resistance in comparison with the control conditions. In addition, the effect exerted by DEEBNA on coronary resistance was significantly blocked $(p=0.05)$ by flutamide. Each bar represents the mean \pm S.E. of 8 experiments.

ene groups bound to both ester and amide groups; at 3.24 and $3.44 \mathrm{ppm}$ for methylene groups bound to both amine groups; at $3.36 \mathrm{ppm}$ for methylene group bound to phenyl group; at 5.04 - 5.95 ppm for protons of alkene 
group and at $6.72-7.59 \mathrm{ppm}$ for phenyl groups. Finally, the spectrum contains other signals at $7.98 \mathrm{ppm}$ for protons involved in both hydroxyl and amino groups. The ${ }^{13} \mathrm{C}$ NMR spectra displays chemical shifts at 12.86 $19.82 \mathrm{ppm}$ for methyl groups; at $21.20-22.90,31.35$ $37.03,38.73,110.52,121.62,139.66$ and $156.08 \mathrm{ppm}$ for steroid nucleus; at $29.59-30.43 \mathrm{ppm}$ for methylene groups bound to both ester and amide groups; at 37.50 ppm for amino groups; at 39.95 for carbon bound to phenyl group; at 67.26 and $86.94 \mathrm{ppm}$ for alkyne group; at $106.34,113.11,119.69,122.05-134.42,139.12$, 141.59 and 151.35 ppm for phenyl groups. Finally, other signals at 116.01 and $137.46 \mathrm{ppm}$ for alkene group; at $163.07 \mathrm{ppm}$ for ester group and at 165.16 for amide group. In addition, the presence of the dehydroisoandrosterone derivative was further confirmed from mass spectrum which showed a molecular ion at $\mathrm{m} / \mathrm{z} 753.54$.

\subsection{Biological Activity}

There are several inotropic agents that have been used to treat heart failure resulting from myocardial ischemia $[3,32]$. Nevertheless, there is scarce information about the effects of danazol and its derivatives on this clinic pathology. Therefore, in this study the inotropic activity of a danazol derivative was evaluated using several strategies.

\subsubsection{First Stage}

The activity induced by danazol and its derivative on the perfusion pressure and coronary resistance in isolated rat heart (Langendorff technique) was evaluated. The results obtained showed that, the danazol derivative significantly increased the perfusion pressure in comparison with the control conditions and danazol. Those experimental data indicate that, the steroid derivative exerts effects on perfusion pressure, which could consequently bring modifications in coronary resistance as happening in other type of steroid derivatives [24,33]. In order to verify this hypothesis, the effects induced by danazol and its derivative on coronary resistance were evaluated. The results indicate that coronary resistance in the presence of the danazol derivative was higher in comparison with control conditions and danazol. All this data suggest that the danazol derivative may induce a positive inotropic activity in the isolated rat heart through of molecular mechanism different than danazol.

\subsubsection{Second Stage}

To characterize the molecular mechanism of positive inotropic effect from the danazol derivative and analyzing these data and other reports [34], which indicate that some steroids stimulate catecholamine production; this phenomenon may induce a positive inotropic effect. Therefore, in this study the effect exerted by the dana- zol derivative on left ventricular pressure was evaluated in the absence or presence of prazosin or metoprolol. The results showed that, the effect induced by the danazol derivative was not inhibited in the presence of these compounds. These data indicate that the molecular mechanism involved in the effects of this steroid-derivative on left ventricular pressure is not through adrenergic activity. Therefore, analyzing these results and other reports which suggest that activity induced by another type of steroid derivatives on blood pressure involved a molecular mechanism via calcium-channels [35]. In addition, it is important to mention that there are reports which shown that some positive cardiotonic agents act by an increase in intracellular $\mathrm{Ca}^{2+}$ and consequently induce an increase in the sensitivity of contractile proteins to $\mathrm{Ca}^{2+}$ ions or by combinations of the two mechanisms [20]. Therefore, in this study, the activity induced by the danazol derivative on left ventricular pressure was evaluated in the absence or presence of nifedipine. The results showed that effect exerted by the danazol derivative was not inhibited in the presence of nifedipine. All these data indicate that activity exerted by the danazol derivative was not via activation calcium channel.

Analyzing experimental data obtained, we also considered validating the effect induced by some steroids on perfusion pressure via prostanglandins [36] and to evaluate the possibility that the activities exerted by the danazol derivative involve stimulation and secretion of prostaglandins. In this study, we evaluated the effect exerted by the danazol derivative on left ventricular pressurein the absence or presence of indomethacin. The results showed that activity induced by the danazol derivative on left ventricular pressure was not blocked by indomethacin. These results indicate that the molecular mechanism involved in the inotropic effect was not via prostaglandins.

On the other hand, in the search of the molecular mechanism involved in the inotropic activity exerted by the danazol derivative and analyzing previous reports, which indicate that danazol, exert its effect by activation of androgen receptor in other type of systes [37]. For this reason, was used flutamide an androgen receptor blocker to determine whether the inotropic activity exerted by the danazol derivative on left ventricular pressure may be through of the androgen receptor activation which is a key requirement for the biological activity as in the case of other androgen derivatives [38]. Our results showed that the effect of the danazol derivative was inhibited by flutamide. Analyzing these data, it was also considered validating the effect induced by flutamide on left ventricular pressure and coronary resistance through of time and compares this phenomenon with activity exerted by the danazol derivative. The results showed that flutamide significantly decreased both left ventricular pressure and 
coronary resistance in comparison with the control conditions; these data are similar to other reports which indicate that flutamide lowers blood pressure in a spontaneously hypertensive rat model [39-41]. In addition, it is important to mention that the activity induced by danazol derivative on the left ventricular pressure was blocked by flutamide through of time. All these data suggest that the molecular mechanism involved in the positive inotropic activity of danazol derivative is via the androgen-receptor such as happening with other type of androgen derivatives [24].

On the other hand, it is important to mention that the danazol derivative is a particularly interesting drug because the positive inotropic activity induced by this steroid derivative involves a molecular mechanism different in comparison with other inotropic drugs [42]. This phenomenon may result in a decrease in adverse effects such as cardiac arrhythmia and ischaemia induced by several cardiotonic agents such as cardiac glycosides and sympathomimetic amine $[43,44]$.

\section{Conclusion}

Experimental data suggest that, positive inotropic activity induced by the danazol derivative on the left ventricular pressure may involve activation of androgen receptor.

\section{REFERENCES}

[1] A. Feldman, "Classification of Positive Inotropic Agents," Journal of the American College Cardiology, Vol. 22, No. 4, 1993, pp. 1223-1227. doi:10.1016/0735-1097(93)90441-3

[2] E. Braunwald and M. Bristow, "Congestive Heart Failure: Fifty Years of Progress," Circulation, Vol. 102, Suppl. 4, 2000, pp. 4-23. doi:10.1161/01.CIR.102.suppl_4.IV-14

[3] J. Kersten, M. Montgomery and S. Pagel, et al., "Levosimendan, a New Positive Inotropic Drug, Decreases Myocardial Infarct Size via Activation of KATP Channels," Anesthesia \& Analgesia, Vol. 90, No. 1, 2000, pp. 5-11. doi:10.1097/00000539-200001000-00003

[4] D. Silverberg, D. Wexler and M. Blum, et al., "The Use of Subcutaneous Erythropoietin and Intravenous Iron for the Treatment of the Anemia of Severe, Resistant Congestive Heart Failure Improves Cardiac and Renal Function and Functional Cardiac Class, and Markedly Reduces Hospitalizations," Journal of the American College Cardiology, Vol. 35, No. 7, 2000, pp. 1737-1744. doi:10.1016/S0735-1097(00)00613-6

[5] W. Wier and P. Hess, "Excitation-Contraction Coupling in Cardiac Purkinje Fibers. Effects of Cardiotonic Steroids on the Intracellular $\left[\mathrm{Ca}^{2+}\right]$ Transient, Membrane Potential, and Contraction," Journal General of Phsiology, Vol. 83, No. 3, 1984, pp. 395-415. doi:10.1085/jgp.83.3.395

[6] A. Clark, "The Mode of Action of Strophanthidin upon Cardiac Tissue," The Journal of Pharmacology \& Experi- mental Therapeutics, Vol. 5, No. 3, 1914, pp. 215-234.

[7] C. Pignier, M. Keller and B. Vié, et al., "A novel SteroidLike Compound F90927 Exerting Positive-Inotropic Effects in Cardiac Muscle," Britih Jounal of Pharmacology, Vol. 147, No. 7, 2006, pp. 772-782. doi:10.1038/sj.bjp.0706673

[8] L. Figueroa-Valverde, F. Díaz-Cedillo and M. López-Ramos, et al., "Synthesis of a New Inotropic Steroid Derivative and Its Relationship with $\log \mathrm{P}, \pi, \mathrm{R}_{\mathrm{m}}, \mathrm{V}_{\mathrm{m}}, \mathrm{P}_{\mathrm{c}}, \mathrm{S}_{\mathrm{t}}$," Asian Journal of Chemistry, No. 23, 2011, pp. 1599. 1604.

[9] M. Gobbini, P. Barassi and A. Cerri, et al., "17 AlphaO-(Aminoalkyl) Oxime Derivatives of 3 Beta, 14 BetaDihydroxy-5 Beta-Androstane and 3 Beta-Hydroxy-14Oxoseco-D-5 Beta-Androstane as Inhibitors of $\mathrm{Na}(+)$, $\mathrm{K}(+)$-ATPase at the Digitalis Receptor," Journal of Medicinal Chemistry, Vol. 44, No. 23, 2001, pp. 3821-3830. doi:10.1021/jm0109208

[10] S. De Munari, A. Cerri and M. Gobbini, et al., "StructureBased Design and Synthesis of Novel Potent $\mathrm{Na}^{+}, \mathrm{K}^{+}$ATPase Inhibitors Derived from a $5 \alpha, 14 \alpha$-Androstane Scaffold as Positive Inotropic Compounds," Journal of Medicinal Chemistry, Vol. 46, No. 17, 2003, pp. 36443654. doi:10.1021/jm030830y

[11] J. Templeton, V. Kumar and D. Cote, et al., "ProgesterOne Derivatives That Bind to the Digitalis Receptor: Synthesis of 14. Beta-Hydroxyprogesterone: A Novel Steroid with Positive Inotropic Activity," Journal of Medicinal Chemistry, Vol. 30, No. 8, 1987, pp. 1502-1505. doi:10.1021/jm00391a038

[12] J. Maixten, I. Bertrand and G. Leliever, et al., "Efficacy and Safety of the Novel $\mathrm{Na}^{+}, \mathrm{K}^{+}$-ATPase Inhibitor $20 \mathrm{R}$ $14 \beta$-Amino $3 \beta$-Rhamnosyl $5 \beta$-Pregnan $20 \beta$-ol in a Dog Model of Heart Failure," Arzneimittel-Forschung, Vol. 42, No. 11, 1992, pp. 301-305.

[13] J. Simard, I. Luthy and J. Guay, et al., "Characteristics of Interaction of the Antiandrogen flutamide with the Androgen Receptor in Various Target Tissues," Molecular and Cellular Endocrinology, Vol. 44, No. 3,1986, pp. 261-270. doi:10.1016/0303-7207(86)90132-2

[14] R. Graham, H. Oates and L. Stoker, et al., "Alpha Blocking Action of the Antihypertensive Agent, Prazosin," Journal of Pharmacology and Experimental Therapeutic, Vol. 201, No. 3, 1977, pp. 747-752.

[15] C. Bengtsson, G. Johnsson and C. Regårdh, "Plasma Levels and Effects of Metoprolol on Blood Pressure and Heart Rate in Hypertensive Patients after an Acute Dose and between Two Doses during Long-Term Treatment," Clinical Pharmacology Therapeutic, Vol. 17, No. 4, 1975, pp. 400-408.

[16] P. Henry, "Comparative Pharmacology of Calcium Antagonists: Nifedipine, Verapamil and Diltiazem," The American Journal of Cardiology, Vol. 46, No. 6, 1980, pp. 1047-1058. doi:10.1016/0002-9149(80)90366-5

[17] T. Owen, I. Ehrhart, W. Weidner, et al., "Effects of inDomethacin on Local Blood Flow Regulation in Canine Heart and Kidney," Experimental Biology and Medicine, Vol. 149, No. 4, 1975, pp. 871-876.

[18] L. Figueroa-Valverde, F. Cedillo, García-Cervera, et al., 
"Design and Synthesis of $N$-[2-(2,3-Dimethoxy-strychnidin-10-ylidenamino)-ethyl]-Succinamic Acid 4-Allyl-2methoxy-phenyl Ester," Bulgarian Chemical Communications, Vol. 45, 2013, in Press.

[19] K. Bayne, "Revised Guide for the Care and Use of Laboratory Animals Available," The Physiologist, Vol. 9, No. 4, 1996, pp. 208-211.

[20] L. Figueroa-Valverde, F. Díaz-Cedillo, López-Ramos, et al., "Inotropic Activity Induced by Carbamazepine-AlKyne Derivative in an Isolated Heart Model and Perfused to Constant Flow," Biomedica, Vol. 31, No. 2, 2011, pp. 232-241.

[21] D. Cermik and B. Taylor, "Regulation of HOXA-10 Expression by Testosterone in Vitro and in the Endometrium of Patients with Polycystic Ovary Syndrome," Journal of Clinical Endocrinology \& Metabolism, Vol. 8, No. 1, 2003, pp. 238-243. doi:10.1210/jc.2002-021072

[22] E. Ahlbom, G. Prins and S. Ceccatelli, "Testosterone Protects Cerebellar Granule Cells from Oxidative StressInduced Cell Death through a Receptor Mediated Mechanism," Brain Research, Vol. 892, No. 2, 2001, pp. 255262. doi:10.1016/S0006-8993(00)03155-3

[23] G. Ashcroft and S. Mills, "Androgen Receptor-Mediated Inhibition of Cutaneous Wound Healing," Journal of Clinical Investigation, Vol. 110, No. 5, 2002, pp. 615-624. doi:10.1172/JCI15704

[24] L. Figueroa, H. Luna, et al., "Synthesis and Evaluation of the Cardiovascular Effects of Two, Membrane Impermeant, Macromolecular Complexes of Dextran-Testosterone," Steroids, Vol. 67, No. 7, 2002, pp. 611-619. doi:10.1016/S0039-128X(02)00011-9

[25] M. Yang and J. Fortune, "Testosterone Stimulates the Primary to Secondary Follicle Transition in Bovine Follicles in Vitro," Biology of Reproduction, Vol. 75, No. 6, 2006, pp. 924-932. doi:10.1095/biolreprod.106.051813

[26] C. Hocht, J. Opezzo, S. Gorzalczany, et al., "Una Aproximación Cinética y Dinámica de Metildopa en Ratas con Coartación Aórtica Mediante Microdiálisis," Revista Argentina de Cardiologia, Vol. 67, No. 6, 1999, pp. 769773.

[27] S. Tu, F. Fang, C. Miao, et al., "One-Pot Synthesis of 3,4-Dihydropyrimidin-2(1H)-Ones Using Boric Acid as Catalyst," Tetrahedron Letters, Vol. 44, No. 4, 2003, pp. 6153-6156. doi:10.1016/S0040-4039(03)01466-7

[28] P. Salehi and N. Fard, "Silica Sulfuric Acid: An Efficient and Reusable Catalyst for the One-Pot Synthesis of 3,4Dihydropyrimidin-2(1H)-Ones," Tetrahedron Letters, Vol. 44, No. 14, 2003, pp. 2889-2891. doi:10.1016/S0040-4039(03)00436-2

[29] R. Yarapathi, S. Kurva and S. Tammishetti, "Synthesis of 3,4-Dihydropyrimidin-2(1H)-Ones Using Reusable Poly(4-vinylpyridine-codivinylbenzene)-Cu(II)complex," Catalysis Communications, Vol. 5, No. 9, 2004, pp. 511-513. doi:10.1016/i.catcom.2004.06.007

[30] F. Shirini, K. Marjani and H. Nahzomi, "Silica Triflate as an Efficient Catalyst for the Solvent-Free Synthesis of 3,4-Dihydropyrimidin-2(1H)-Ones," Arkivoc, Vol. 2007, No. 1, 2007, pp. 51-57. doi:10.3998/ark.5550190.0008.106
[31] R. Crossland and K. Servis, "Facile Synthesisof Methanesulfonate Esters," Journal Organic Chemistry, Vol. 35, No. 9, 1970, pp. 3195-3196. doi:10.1021/jo00834a087

[32] M. Wadie and B. Fam, "Effect of Coronary Vasodilator Drugs on Retrograde Flow in Areas of Chronic Myocardial Ischemia," Circulation Research, Vol. 15, 1964, pp. 355-365. doi:10.1161/01.RES.15.4.355

[33] L. Figueroa-Valverde, F. Díaz-Cedillo, E. Diaz, et al., "Effect Induced by Hemisuccinate of Pregnenolone on Perfusion Pressure and Vascular Resistance in Isolated Rat Heart," African Journal of Pharmacy \& Pharmacology, Vol. 3, No. 5, 2009, pp. 234-241.

[34] I. Charalampopoulos, E. Dermitzaki, L. Vardouli, et al., "Dehydroepiandrosterone Sulfate and Allopregnanolone Directly Stimulate Catecholamine Production via Induction of Tyrosine Hydroxylase and Secretion by Affecting Actin Polymerization," Endocrinology, Vol. 146, No. 8, 2005, pp. 3309-3318. doi:10.1210/en.2005-0263

[35] L. Figueroa-Valverde, F. Díaz-Cedillo, M. López-Ramos, et al., "Changes Induced by Estradiol-Ethyl-Enediamine Derivative on Perfusion Pressure and Coronary Resistance in Isolated Rat Heart: L-Type Calcium Channel," Biomedical Papers, Vol. 155, No. 1, 2011, pp. 27-32. doi:10.5507/bp.2011.018

[36] C. Sheillan, C. Ody, F. Russo, et al., "Differential Aspects of Sex Steroids on Prostaglandin Secretion by Male and Female Cultured Piglet Endothelial Cells," Prostaglandins, Vol. 26, No. 1, 1983, pp. 3-12. doi:10.1016/0090-6980(83)90069-2

[37] L. Krey, R. Robbins and B. McEwen, "Danazol Suppression of Luteinizing Hormone Secretion: A Role for Danazol-Androgen Receptor Interaction within the BrainPituitary Complex," Fertility and Sterility, Vol. 35, No. 4, 1981, pp. 467-472.

[38] L. Figueroa-Valverde, E. Diaz-Ku and F. Diaz-Cedillo, "Effects of Danazol and Danazol Hemisuccinate on Perfusión Pressure and Vascular Resistance," Acta Bioquímica Clínica Latinoamericana, Vol. 44, No. 1, 2010, pp. 37-45.

[39] J. Reckelhoff, H. Zhang, K. Srivastava, et al., "Gender Differences in Hypertension in Spontaneously Hypertensive Rats: Role of Androgens and Androgen Receptor," Hypertension, Vol. 34, 1999, pp. 920-923. doi:10.1161/01.HYP.34.4.920

[40] A. Caple, D. Seachrist and D. Dunphy, "Sodium-Induced Rise in Blood Pressure Issuppressed by Androgen Receptor Blockade," American Journal of Physiology, Heart and Circulatory Physiology, Vol. 280, No. 4, 2001, pp. H1793-H1801.

[41] F. Zheng, P. Wang and J. Kuebler, "Flutamide Induces Relaxation in Large and Small Blood Vessels," Archives of Surgery, Vol. 137, No. 10, 2002, pp. 1180-1186. doi:10.1001/archsurg.137.10.1180

[42] T. Akera and M. Brody, "The Role of $\mathrm{Na}^{+}, \mathrm{K}^{+}$-ATPase in the Inotropic Action of Digitalis," Pharmacology Review, Vol. 29, No. 3, 1977, pp. 187-220.

[43] J. Simard, I. Luthy and J. Guay, "Characteristics of Interaction of the Antiandrogen Flutamide with the Androgen 
Receptor in Various Target Tissues," Molecular Andular\& Endocrinology, Vol. 44, No. 3, 1986, pp. 261-270.

[44] L. Pierard, C. Berthe, A. Albert, et al., "Haemodynamic
Alterations during Ischaemia Induced by Dobutamine Stress Testing," European Heart Journal, Vol. 10, No. 9, 1989, pp. 783-790. 